\title{
A new law on advance directives in Germany
}

\author{
U Wiesing, ${ }^{1}$ R J Jox, ${ }^{2}$ H-J Heßler, ${ }^{3}$ G D Borasio ${ }^{2}$
}

1 Institut für Ethik und Geschichte der Medizin, Universität Tübingen, Tübingen, Germany

${ }^{2}$ Interdisziplinäres Zentrum für Palliativmedizin, Klinikum der Universität München, München, Germany

${ }^{3}$ Oberlandesgericht München, München, Germany

\section{Correspondence to} Dr Urban Wiesing, Institut für Ethik und Geschichte der Medizin, Universität Tübingen, Gartenstr 47, D-72076

Tübingen, Germany; urban. wiesing@uni-tuebingen.de

Received 12 March 2010 Revised 28 May 2010 Accepted 13 June 2010

\section{ABSTRACT}

This article presents the new German law on advance directives from 1 September 2009. The history of the parliamentary process of this law is described, the present regulations are explained, their relevance for medical practice discussed and shortcomings are identified. Finally, the new law is compared with other regulations in the international context. Previously established legal practice in Germany has now become largely confirmed by the new law: An advanced directive must be respected in any decision concerning medical treatment, regardless of the stage of the illness. It can be informally revoked at any time, even with limited decision-making capacity. Nobody may be obliged to issue a directive in any way. Advance directives do not need notarisation or routine updating after certain time intervals. Provided that the patient, who is no longer mentally competent, has issued a lasting power of attorney (Bevollmächtiger), or provided that the patient has been appointed a healthcare proxy by the courts (Betreuer), this authorised surrogate must assert the patient's will. The role of the guardianship court is clarified: it only needs to be involved in cases of disagreement as to the patient's will. The new German law thus combines more legal certainty with a liberal emphasis on patient autonomy and flexible, adaptable regulations.

Medical decision-making at the end of life is frequently complicated by the fact that patients lose the capacity to decide about their treatment. In advance directives, patients can anticipate future medical situations and document prospectively how they want to be treated in these situations. As a considerable and increasing proportion of patients in Europe use advance directives, ${ }^{12}$ the legislators in many European countries have seen the need to clarify this issue in statutory laws. ${ }^{3}$ The European Convention on Human Rights and Biomedicine from 1997 includes a statement that previously expressed treatment wishes of patients are to be taken into account, ${ }^{5}$ and recently the Council of Europe has issued recommendations on principles concerning advance directives to its member states. ${ }^{6}$ Germany has now followed many neighbour countries in Europe and introduced a law on advance directives. ${ }^{7}$ We will present the regulations, discuss their relevance for medical practice, identify shortcomings and comment on the new law in the international context.

\section{NEED TO REFORM THE LAW}

Advance directives have become increasingly important in recent years in Germany. More and more Germans complete such documents, and the German Medical Association has granted them a greater role in medical decision-making. Nevertheless, no statutory law has been regulating advance directives. Authoritative case law and ethical guidelines by the German Medical Association have offered some orientation for healthcare professionals and the general public.

Yet judicial decisions were often inconsistent and fell short of providing an unequivocal clarification of the law on advance directives. This was especially true for a technically faulty judgement of the Federal Court from 17 March 2003, which, although establishing the binding nature of advance directives, included contradictory statements in a series of essential points. ${ }^{8}$ What remained disputed after the judgement were, in particular, questions concerning the scope of advance directives and the role of the guardianship court: was the validity of advance directives restricted to situations in which patients were in the terminal stages of incurable diseases? Was there an obligation to obtain court approval for all cases of treatment withdrawal or withholding on the basis of advance directives or only if there was disagreement between the parties involved?

Consequently, the then minister of justice, Brigitte Zypries, instituted a working group called 'Patient Autonomy at the End of Life' that presented the outline of a law on advance directives in June 2004. ${ }^{9}$ This report formed the basis of a draft bill written by a cross-party group of members of parliament (MPs), led by the Social Democrat, Joachim Stünker. ${ }^{10}$ It emphasised the right of patient self-determination and represented a liberal interpretation of the hitherto existing case law.

An opposing bill, authored by a cross-party group around the conservative Christian Democrat MP, Wolfgang Bosbach, limited the bindingness of advance directives to illnesses with an 'irreversible fatal progression'. It also placed high formal hurdles in front of the directives, such as requiring authorised notarisation. A third bill, introduced by Wolfgang Zöller, an MP of the Christian Social Union, emphasised the dialogue between relatives and physicians before implementing an advance directive, but did not include any restriction regarding the patient's kind of illness.

After a failed attempt to merge the Stünker and Zöller bills, the Stünker group incorporated two core principles of the Zöller draft shortly before the vote in the federal parliament (Bundestag). These amendments emphasised the role of the medical indication in end-of-life decision-making and the importance of dialogue and communication in implementing advance directives. After lifting the restriction of voting along party lines, the law was passed with votes from the majority of the Social Democrats, the Liberal Democrats, the MPs from 
the Leftist Party, a group of Green Party MPs, but only one MP of the Christian Democratic and Christian Social Unions. The law became effective on 1 September 2009. The voting behaviour is noteworthy in three regards: (1) after a parliamentary debate over two legislative periods and numerous voices to withdraw legislation on this issue, it is surprising that there was actually a law passed in the end; (2) the German Bundestag has recently voted far more conservatively on biopolitical issues (eg, genetic engineering law, stem cell law, embryonic protection law); (3) although the German MPs were officially liberated from party whip, the parties did in fact vote rather corporately.

\section{THE NEW LEGAL SITUATION}

The new German law is oriented along previous judicial decisions. A written advance directive authored by a mentally competent patient for the event of future incompetence is now legally binding according to $\S 1901 a .1$ of the German Civil Code (Bürgerliches Gesetzbuch, BGB). This binding directive must be respected in any decision concerning medical treatment, regardless of the stage of illness ( $\$ 1901$ a.3 BGB). Provided that the patient, who is no longer mentally competent, has issued a lasting power of attorney (Bevollmächtiger), or provided that the patient has been appointed a healthcare proxy by the courts (Betreuer), this authorised surrogate must assert the patient's will vis-à-vis the physician, the nurses and the institutions in which the patient is being treated. When no written advance directive exists, the treatment preferences or the patient's presumed will must be determined based on concrete evidence, such as previous oral statements ( $\$ 1901$ a.2 BGB).

What the patient's will might be in concrete terms and whether the situation at hand corresponds with the situation that was mentioned in the advanced directive must be determined in a communication process between the physician and the patient's surrogate, whereas the physician has to determine the medical indication in advance ( $\$ 1901 b$ BGB). Approval by the adult guardianship court is not necessary if the physician and the surrogate agree on the patient's will in a concrete situation ( $\$ 1904$ BGB).

The law states that advance directives are only valid in writing. According to $\S 126$ of the German Civil Code, a written statement must always be signed by hand; this formal requirement is also satisfied by the often-used checkbox forms as long as it includes the patient's signature. Notarisation is not necessary. A verbal statement, although not recognised as an advance directive, is still of legal value. In determining a patient's will, a verbal statement is recognised either as an expression of preferred treatment, when referring directly to a specific treatment in question, or as a clear sign of the presumed will of the patient. The law also makes explicit that only an adult (18 years or above) can establish an advance directive.

In line with traditional guardianship law, the new law does not explicitly refer to the binding nature of advance directives, but rather presupposes it. ${ }^{10}$ As the advance directive is regarded as binding, the authorised surrogate must abide by it and ensure that it is implemented by doctors, nurses and institutions.

An advance directive that is clearly applicable to the circumstances of a case can be followed directly by the physician even when there is no surrogate that represents the patient as decision-maker. Due to the principle of necessity in guardianship law ( $\$ 1896.2$ BGB), a proxy does not have to be named in such a situation, as he or she is not needed to implement the patient's will. The attending physician, however, has to be certain that the advance directive accurately matches the situation.
The law, as spelled out in $\S 1901 \mathrm{~b}$ BGB, intends that the physician, after examining the medical indication, will determine the patient's will in close communication with the patient's surrogate and, if time allows, by enlisting the aid of 'close relatives and other persons the patient trusted'. This procedure will especially serve to safeguard the decision-making process and protect the physician and surrogate in ambiguous cases. Those not abiding by the procedure will risk misinterpreting the situation and then paying the legal consequences if in hindsight another reading of the advance directive is deemed more appropriate. Therefore, the higher the level of uncertainty regarding the patient's will, the higher the level of care that is needed in guiding and documenting the dialogue between the participating individuals.

\section{MEDICAL INDICATION}

The most important legal prerequisites for performing any medical treatment are the medical indication and the patient's informed consent. The physician will first evaluate the medical indication for a specific treatment for the individual patient in the specific situation, based on scientific evidence and the state of the art. The physician must decide whether the treatment in question represents a benefit to the patient that outweighs the risks and disadvantages. The following two questions must be addressed: (1) What is the intended goal of the treatment under discussion? (2) Is there a realistic probability that the intended goal will be attained using this treatment?

As for the first question, every medical procedure must serve a reasonable treatment goal in the first place. Examples of generally accepted treatment goals include healing, prolongation of life, rehabilitation or maintenance of quality of life. If no reasonable treatment goal is available, such as when all possible measures would only marginally prolong the process of dying, the medical procedure in question is not warranted and should not be carried out.

As for the second question, assuming a reasonable treatment goal has been identified, the physician must decide whether, according to existing evidence, there is a realistic chance that the planned medical action will achieve this goal. Any measure that cannot or in all likelihood will not achieve the intended goal is not warranted (eg, artificial nutrition and hydration in advanced dementia). ${ }^{11}$

\section{INDICATION AND THE PATIENT'S WILL}

It is only when the medical indication has been affirmed or at least accepted with sufficient probability that the attending physician will inform the patient or the patient's representative about the indicated treatment and seek informed consent for it by clarifying the patient's will (figure 1). Eliciting the patient's will and establishing a surrogate are superfluous if a medical indication is lacking. Conversely, no medical procedure, even though it may be clearly indicated, can be performed against the patient's will (eg, blood transfusions for Jehovah's Witnesses). If a decision is based on the lack of medical indication, this can prevent emotional burden for family members arising from the idea that they may be responsible for the death of their loved one. ${ }^{12}$

Communicating the lack of a medical indication for lifesustaining treatment and the necessity to redirect the treatment goal from a curative to a palliative one represents a huge challenge for any physician. It is a challenge that should be met with care, empathy, and an emphasis on the variety of palliative treatments that are available to reduce suffering at the end of life. 


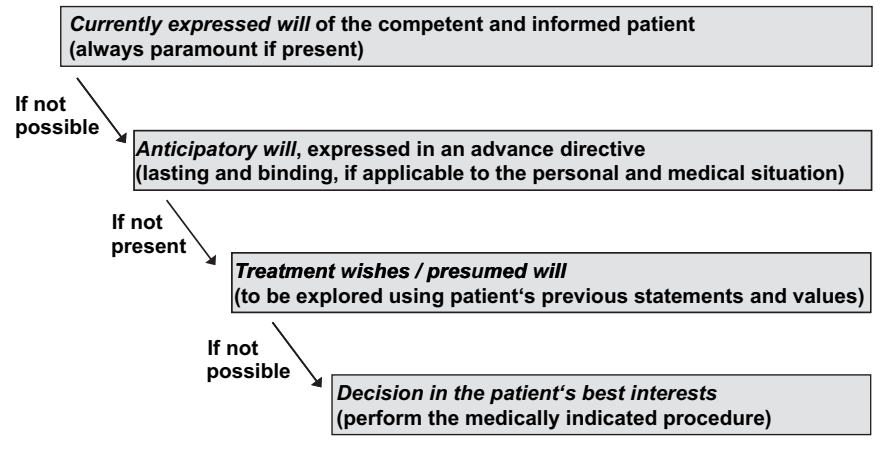

Figure 1 The patient's will: central criterion of medical decision making.

The flow chart in figure 2 offers practical assistance on how best to implement the German law on advance directives. As a first step, the physician evaluates the medical indication for the treatment in question. If the treatment is indicated, the physician then determines whether the patient has decisionmaking capacity. This is the case if the patient is able to comprehend the scope and consequences of the proposed treatment and to form a voluntary decision on the basis of his personal values (decision-making capacity is different from the legal capacity for affairs). In cases of doubt, a psychiatrist or neurologist should be consulted.

The patient who possesses decision-making capacity will be informed on the benefit and risks of the planned treatment as well as on alternative measures. If the decision is difficult, it is recommended to include, with the patient's consent, the next of kin into the dialogue. Before starting or stopping the treatment, the decision should be thoroughly documented. In the event that the patient lacks decision-making capacity, the physician must first interpret any existing advance directive in cooperation with the patient's surrogate (if present) and the patient's family. If there is an advance directive that is clearly applicable to the clinical situation at hand, the physician must treat the patient according to the anticipatorily expressed will, unless concrete information is available that the patient had revoked the directive in the meantime.

If there is no advance directive or the directive does not fit the situation at hand, the physician should ascertain whether the patient has a legally authorised surrogate. If this is not the case and the clinical situation is acute, then the physician should seek consensus with the patient's family over the patient's presumed will and act accordingly. If time does not allow a consensus in an emergency situation, the medically indicated treatment should be performed. If there is sufficient time and no imminent danger, the court should be asked to appoint a guardian who will then be a legally authorised representative of the patient.

After a guardian has been appointed, the patient's will is to be determined and documented in a dialogue-based process. Subsequent approval of the guardianship court is only necessary if the physician and surrogate disagree on the patient's will. Their views as to what might be better or worse for the patient's wellbeing are legally irrelevant as the only guidance must be the patient's will. Here, German law is much more oriented towards the principle of autonomy (patient's will) than beneficence (patient's best interest). However, some scholars even dispute the possibility that there might be a 'best interest' in conflict with the patient's will. ${ }^{13}$

When the decision is made to administer a certain treatment, the physician is obliged to check continually throughout the course of treatment whether the indication further persists.
Particularly at the end of life, indications for such procedures as blood transfusion, corticosteroids or artificial nutrition may change.

\section{A LACK OF MEDICAL COUNSELLING}

Previously established legal practice in Germany has now become largely confirmed by the new law. The much debated question whether to limit advance directives to terminal diseases has been negated. The role of guardianship courts has been clarified. Several points are now explicitly regulated: An advance directive can be informally revoked at any time, even with limited decision-making capacity. Hospitals and nursing homes are not permitted to require advance directives as prerequisites for admission, as nobody may be obliged to issue a directive in any way. Advance directives do not need notarisation or routine updating after certain time intervals. The new German law thus combines more legal certainty with a liberal emphasis on patient autonomy and flexible, adaptable regulations. Nevertheless, ambiguities, points of criticism and recommendations for improvements should be considered.

According to the law, the physician has to determine "which medical procedure, in view of the overall condition and prognosis of the patient, is indicated' ( $\$ 1901 \mathrm{~b}$ BGB). Why does the law explicate what doctors should be doing at least since the writings of Hippocrates, namely to determine the individual medical indication on the basis of prognosis? It seems that doctors have not always observed this fundamental principle in their work. Apparently they have sometimes focused on the technically feasible rather than the individually indicated treatment.

The law does not specify how to solve cases of disagreement over the medical indication. Indications are most often not mathematically determined; they are a matter of judgement by the physician, but what happens if the surrogate or a family member questions the indication? The law does not specify whether a second opinion should be sought. It is recommendable that physicians themselves present this possibility as a means of strengthening the trust relationship between the involved parties.

The law does not require counselling before writing an advance directive. An advance directive is ultimately a form of instruction by a patient to his future physician concerning medical procedures. ${ }^{14}$ Would it therefore not be completely sensible to seek medical counselling before writing an advance directive? During the drafting and legislative passage of the law, it was articulated that lay organisations may offer competent counselling. It is important to point out that non-medical professionals may counsel patients regarding their values and attitudes, but they are not in a position to offer advice on medical details. Medical facts must be addressed when formulating an advance directive, especially when the progression of an illness is foreseeable. For this reason, medical counselling before completion of advance directives is more than just desirable and needs to be included into the service and benefits catalogue of health insurance companies.

\section{MINORS}

The jurisdiction has long recognised that minors may individually have the necessary capacity to consent to certain forms of treatment. What does this mean with regard to advance directives? Oddly enough, the law requires authors of advance directives to be adult (18 years or more), but does not comment on the problem of minors with decision-making capacity. It is, however, a general principle of German law that parents have to respect the growing capability and interest of their children to 
Figure 2 Flow chart illustrating the recommended decision-making process when having to decide on medical procedures (diagnostic or therapeutic).

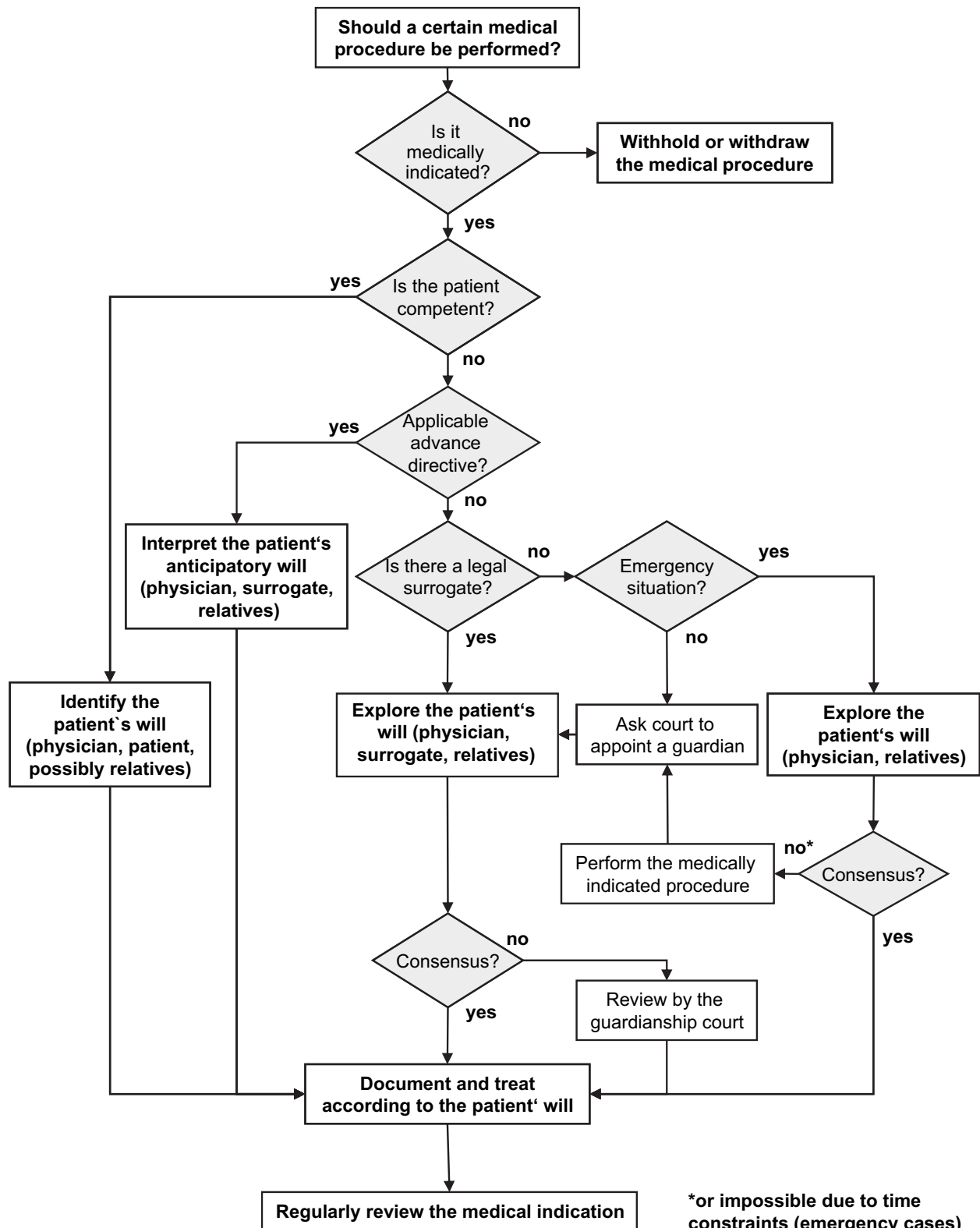

constraints (emergency cases) participate in decision-making concerning their welfare. Therefore, the expressed will of children and adolescents is to be considered when parents make healthcare decisions for them. Whether a well-reflected rejection of life-sustaining treatment by a thoroughly informed teenager can be overruled by the parents has yet to be determined in court. In any case, the role of the physician is to try the utmost to bring about consensus among family members in such situations to avoid complicated grieving processes. $^{15}$

From the medical as well as legal point of view, it is recommended to combine an advance directive with a lasting power of attorney. ${ }^{14} 16$ Clinical experience suggests that an authorised representative alone can better represent the interests of the patient than an advance directive alone without a surrogate decision-maker

\section{GERMAN LAW IN THE EUROPEAN CONTEXT}

Altogether, the new legal regulations in Germany harmonise well with the laws that other European countries have introduced recently. ${ }^{417}$ All of them affirm that an advance directive is in general a legally binding documentation of the patient's will. Although Germany is notorious for having meticulous legal regulations, this law is rather sketchy: it eschews many controversial issues like, for example, the decision-making capacity, the revocation of directives, the treatment of minors or advance care counselling. Compared with the German law, an example of a comprehensive and detailed statute is the English Mental Capacity Act 2005. ${ }^{17} 18$ In the international context the German law is quite liberal in that it does not stipulate many requirements for advance directives to be legally binding. Germany's neighbour Austria, for example, requires patients to get medical counselling and judicial testimony every 5 years if they want to have a legally binding form of advance directive (as opposed to a non-binding one that has to be taken into account when determining the presumed will of the patient). ${ }^{19}$ Moreover, the German law is quite unique in emphasising the authority of the medical indication as judged by the physician, thus opening the way for end-of-life decisions based on futility.

An example for a very different way of dealing with the legal questions posed by advance decision-making can be found in 
Italy, where one of the two chambers of parliament (the Senate) has already passed a bill that would render advance directives explicitly non-binding for the physician and would exclude artificial nutrition and hydration 'in any form' from the treatments that can be refused by the patients in an advance directive. The bill, which has been strongly endorsed by the Vatican, has been sharply criticised by the Italian Society for Palliative Care as a measure that would oblige physicians to practise contrary to the patients' best interests. The final legislative outcome of the bill is unclear at present. ${ }^{20}$

\section{CONCLUSIONS}

With the new German law on end-of-life decisions, legal certainty has been attained with regard to the binding nature of advance directives. Specific questions still need to be addressed. What appears paramount is avoiding an unnecessary legalism in the doctor-patient relationship at the end of life. Therefore it is to be welcomed that, according to the new law, the guardianship court only needs to be involved in cases of disagreement as to the patient's will. Just as important is the clarification that, when medical indication is lacking or when an unambiguous advance directive is available, the appointment of a legal guardian is unnecessary.

The goal of medicine at the end of life should always be to view the patient and family as a unit of care, to respect the patient autonomy and at the same time to shape decisionmaking and communication in a manner that does not lead to additional suffering for the family during the period of mourning. The new German law offers an appropriate legal framework for this goal but now needs to be disseminated to and implemented by all healthcare professionals involved in end-of-life care.

Competing interests None.

Provenance and peer review Not commissioned; externally peer reviewed.

\section{REFERENCES}

1. Van Oorschot B. Patientenverfügungen aus Bevölkerungs- und Patientensicht. Eine Übersicht über empirischen Studien aus dem deutschen Sprachraum. Bull Soc Sci Med Grand Duche Luxemb 2008;3:443-54

2. Rurup ML, Onwuteaka-Philipsen BD, van der Heide A, et al. Frequency and determinants of advance directives concerning end-of-life care in The Netherlands. Soc Sci Med 2006;62:1552-63.
3. Lautrette A, Peigne V, Watts J, et al. Surrogate decision makers for incompetent ICU patients: a European perspective. Curr Opin Crit Care 2008;14:714-19.

4. Andorno R, Biller-Andorno N, Brauer S. Advance health care directives: towards a coordinated European policy? Eur J Health Law 2009;16:207-27.

5. Council of Europe. Convention for the protection of human rights and dignity of the human being with regard to the application of biology and medicine: convention on human rights and biomedicine. Oviedo: The Council, 1997. http://conventions.coe.int/ Treaty/EN/Treaties/html/164.htm (accessed 27 May 2010).

6. Council of Europe. Recommendation CM/Rec(2009)11 of the Committee of Ministers to member states on principles continuing powers of attorney and advance directives for incapacity. Eur J Health Law 2010;17:205-10.

7. Bundesministerium der Justiz. Drittes Gesetz zur Änderung des Betreuungsrechts. Bundesgesetzblatt Teil I Nr 48, 31 July 2009. http://www.bmj.bund.de/files/-/ 3906/Drittes_Gesetz_Aenderung_Betreuungsrecht_Bundesgesetzblatt.pdf laccessed $1 \overline{4}$ Oct $2 \overline{010}$ )

8. Bundesgerichtshof. Beschluss vom 17.3.2003, AZ XII ZB 2/03. http://juris. bundesgerichtshof.de/cgi-bin/rechtsprechung/document.py?Gericht=bgh\&Art= encnr=25809\&pos $=0$ \&anz $=1$ (accessed 14 Oct 2010)

9. Bundesministerium der Justiz. Patientenautonomie am Lebensende. Ethische rechtliche und medizinische Aspekte zur Bewertung von Patientenverfügungen. Bericht der Arbeitsgruppe "Patientenautonomie am Lebensende". 10 June 2004. http://www.bmj.bund.de/files/-/695/Bericht AG Patientenautonomie.pdf (accessed 27 May 2010).

10. Stünker J, Kauch M, Jochimsen L, et al. Entwurf eines Dritten Gesetzes zur Änderung des Betreuungsrechts. Bundestag-Drucksache;16/8442. http://www.bmj. bund.de/files/50f61612050a95cb6524a0b8e9a438f9/3053/Patientenverfuegung Entwurf Stuenker Stand 03 2008.pdf (accessed 14 Oct 2010).

11. Sampsōn EL, Candy B, Jones L. Enteral tube feeding for older people with advanced dementia. Cochrane Database Syst Rev 2009;2:CD007209. doi:10.1002/14651858. CD007209.pub2.

12. Borasio GD. Patientenautonomie und Strafrecht in der Sterbebegleitung. Referat und Thesen. In Verhandlungen des 66. Deutschen Juristentages Stuttgart 2006 München: CH Beck, 2007;Bd. II/1:N55-71.

13. Lipp V. Die gegenwärtige Rechtslage zur "Sterbehilfe". In: Meier C, Borasio GD, Kutzer K, eds. Patientenverfügung. Ausdruck der Selbstbestimmung - Auftrag zur Fürsorge. Münchner Reihe Palliative Care. Stuttgart: Kohlhammer, 2005; Vol. 1:56-87.

14. Bayerisches Justizministerium. Vorsorge für Unfall, Krankheit und Alter durch Vollmacht, Patientenverfügung, Betreuungsverfügung. München: CH Beck, 2009.

15. Jox RJ, Führer M, Borasio GD. Patientenverfügung und Elternverfügung. "Advance care planning" in der Pädiatrie. Monatsschr Kinderheilkd 2009;157:26-32.

16. Bundesärztekammer, Zentrale Ethikkommission bei der Bundesärztekammer. Empfehlungen der Bundesärztekammer und der Zentralen Ethikkommission bei der Bundesärztekammer zum Umgang mit Vorsorgevollmacht und Patientenverfügung in der ärztlichen Praxis. Dtsch Ärztebl 2010;107:877-82.

17. Jox RJ, Michalowski S, Lorenz J, et al. Substitute decision-making in medicine: comparative analysis of ethico-legal discourse in England and Germany. Med Health Care Philos 2008;11:153-63.

18. Halliday S. Advance decisions and the mental capacity act. Br J Nurs 2009;18:697-9.

19. Körtner UH. Patient advance directive in Austria: ethical discussions. Bull Soc Sci Med Grand Duche Luxemb 2008;3:279-87.

20. Borasio GD. In Italia i sondini hanno più diritti dei malati? Micromega 2009;2:101-7 


\section{A A new law on advance directives in Germany}

U Wiesing, R J Jox, H-J Heßler, et al.

J Med Ethics 2010 36: 779-783

doi: 10.1136/jme.2010.036376

Updated information and services can be found at:

http://jme.bmj.com/content/36/12/779.full.html

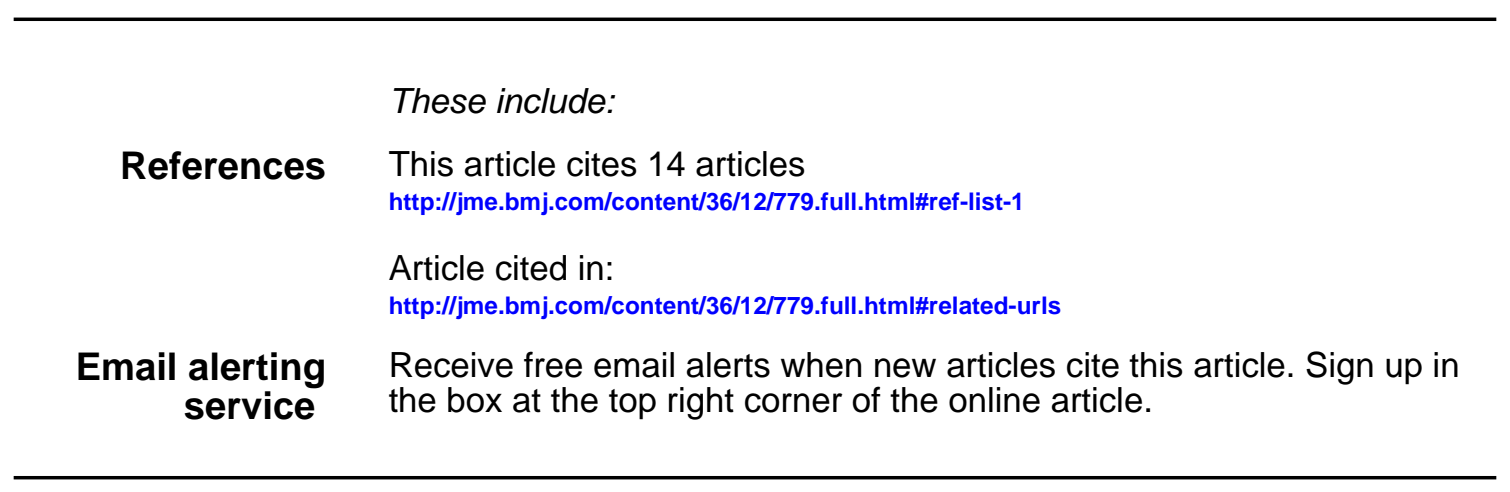

Notes

To request permissions go to:

http://group.bmj.com/group/rights-licensing/permissions

To order reprints go to:

http://journals.bmj.com/cgi/reprintform

To subscribe to BMJ go to:

http://group.bmj.com/subscribe/ 